Tropical Journal of Applied Natural Sciences
Trop. J. Appl. Nat. Sci., 2(2): 1-9 (2018)
ISSN: 2449-2043
https://doi.org/10.25240/TJANS.2018.2.2.01

\title{
Environmental Impact of Abattoir Effluents on Surface Waters of River Idemili
}

\author{
Ibemenuga, K. N. \\ Department of Biological Sciences, Faculty of Natural Sciences, Chukwuemeka Odumegwu Ojukwu University, Anambra State, Nigeria.
}

E-mail: jesusvesselofhonour@yahoo.com; Phone no: +234812621299

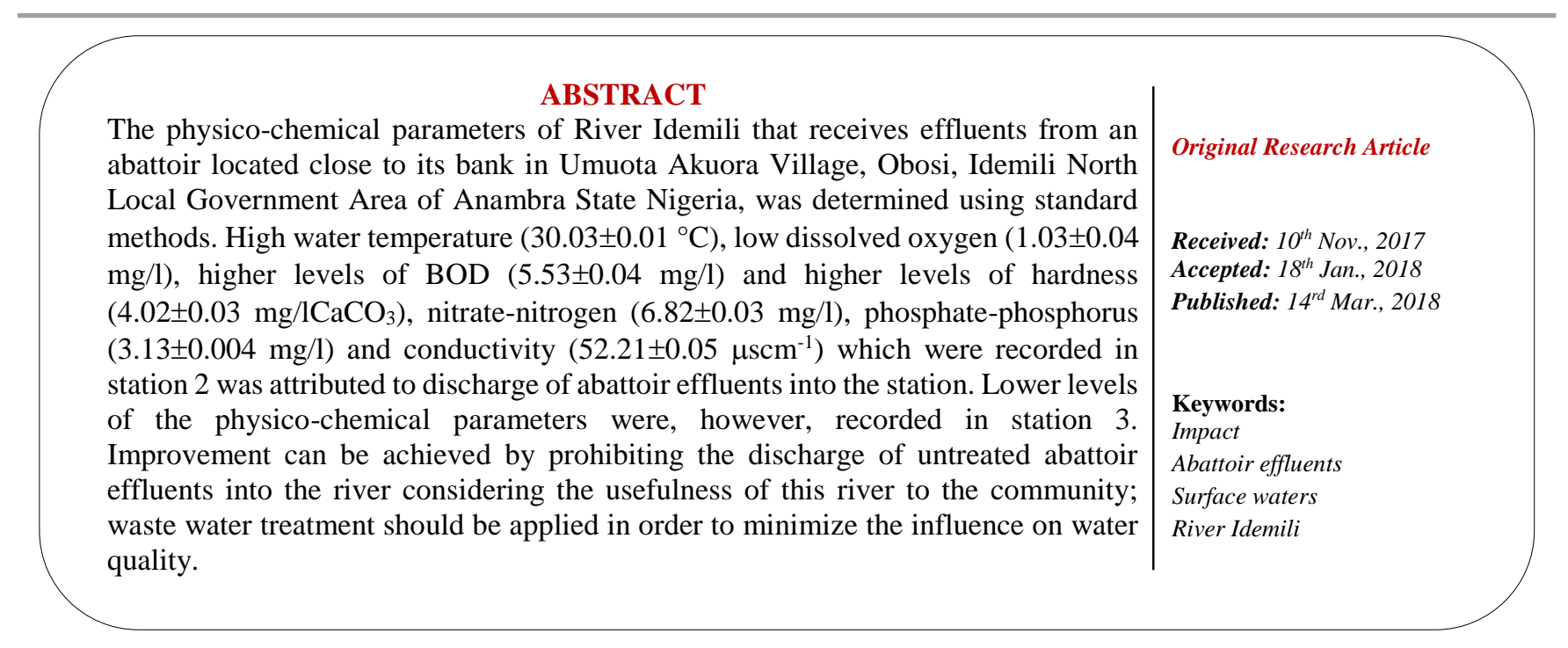

\section{INTRODUCTION}

Water is a finite resource that is very essential for human existence, agriculture, industries, etc (Calamari and Naeve, 1994; Aina and Adipe, 1996). It could be described as the engine of life because water in its varied forms accounts for more than 70 percent of the entire earth and life forms. Fresh water has become scarce commodity due to over exploitation and pollution (Gupta and Shunkle, 2006; Patil and Tijane, 2001; Singh and Mathur, 2005).

Rivers are the most important freshwater resources for man. Unfortunately, river water in developing areas is increasingly being polluted by man. Several rivers in urban and semi urban areas of Nigeria have been polluted with untreated solid waste and waste waters. This high pollution status threatens and in many cases, has already altered the ecological balance of most rivers in Nigeria (Arimoro and Osakwe, 2006; Zabbey and Hart, 2006; Arimoro and Ikomi, 2008). Untreated organic effluents from abattoir contaminants flushed into streams particularly in areas of human activities pollute rivers and streams.

Mason (1996) reported that the excessive production of organic matter leads to the buildup of "sludge" and the mineralization process consumes all dissolved oxygen from a water column. Organic effluents also frequently contain large quantities of suspended solids which reduce the light available to photosynthetic organisms and on setting out, alter the characteristics of river bed, rendering it an unsuitable habitat for many organisms (Raheem and Morenikeji, 2008). This study presents a comprehensive report on the influence of abattoir wastes on the physico-chemical parameters of River Idemili.

\section{MATERIALS AND METHODS}

\subsection{Description of the Study Area}

River Idemili (Figure 1) is a hydrographic stream in Southeastern Nigeria. It is located at an elevation of 64 meters above sea level and its coordinates are $6^{\circ} 7^{\prime} 0^{\prime \prime} \mathrm{N}$ and $6^{\circ} 46^{\prime} 0^{\prime \prime}$ E. The river lies approximately 7 kilometers south of Onitsha, along the old Owerri-Onitsha Trunk road. This tropical area has an average annual rainfall of $2000 \mathrm{~mm}$. The river's tributaries include Idemili stream and close to this river is an abattoir house located at its bank. Slaughtering of cows occurs within the slaughter house while roasting of cow heads, skin and hind limbs with wood and condemned tyres occur in the open. These activities have darkened the soil within the roasting area while waste water from washing of roasted cow parts and abattoir drain into the river. Three stations were sampled. 


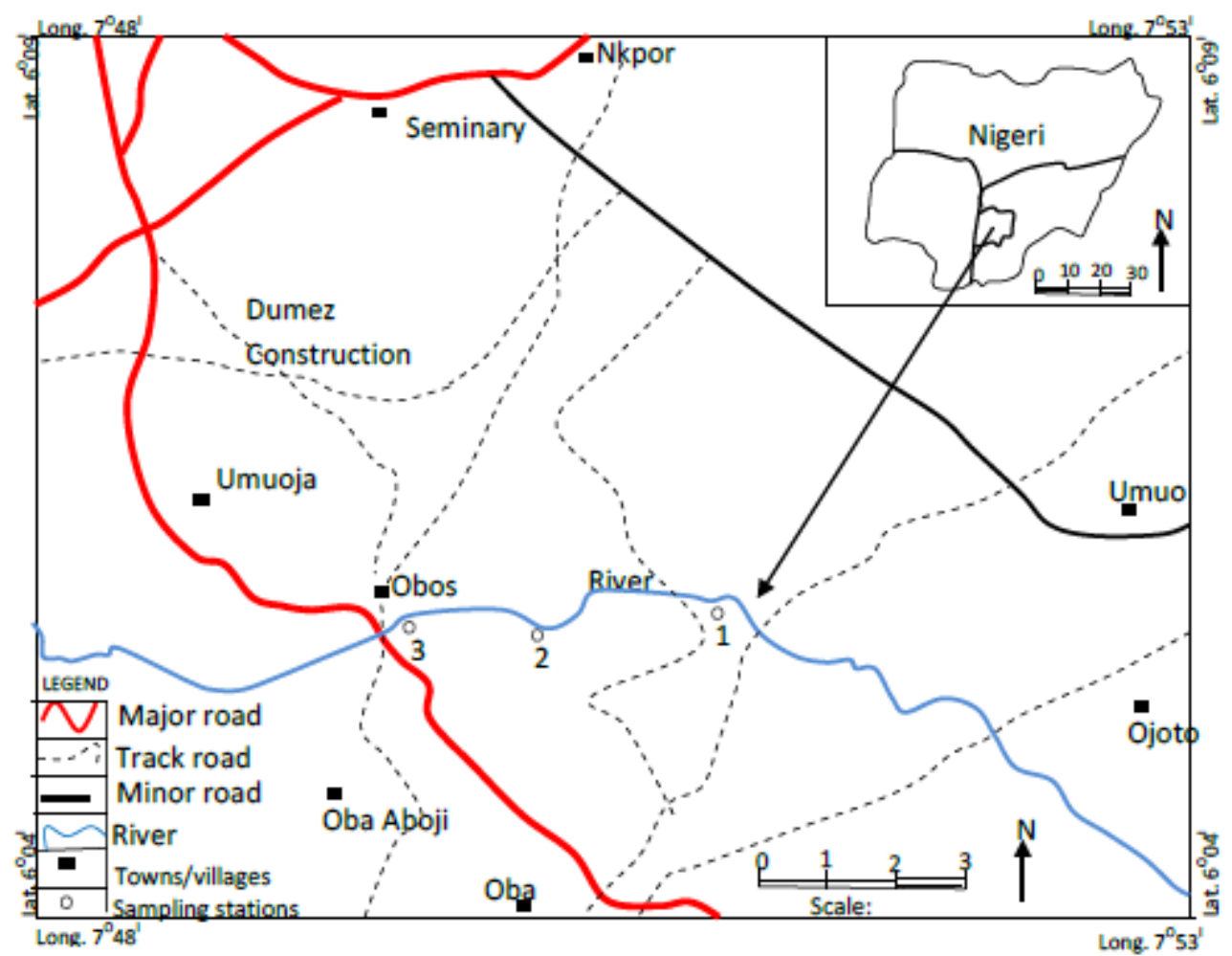

Figure 1: Map of the Study Area.

\section{Station 1}

This station had a mixture of sandy and loamy soil with intensive agricultural activities occurring around the river, It is wide and deep. Light penetrates directly into this station. There are no canopies of leaves and true aquatic littoral flora consists of macrophytes growing along the river banks which include Pennisetum purpereum, Colacasia esculenta and Elaeis guineensis.

\section{Station 2}

The abattoir is located close to this station. It has sandy, loamy and clayey soil. The soil is mostly oily because of the slaughtering activities. Human activities in and around this station include slaughtering of cows, roasting and washing of cow hides and viscera. Macrophytes in this station include Bambuseae sp., Heteropogon controtus and Raphia hookeri.

\section{Station 3}

This station is located near the bridge across the river that is along Owerri-Onitsha express road. The soil is sandy and human activities in and around this station includes performing of rituals by idol worshippers, washing of motorcycles, swimming and dumping of refuse. Psidium sp., Algae and Heteropogon contortus were among aquatic plants observed in this station.

\subsection{Collection of water samples}

Water sample collection was done forth nightly for twelve months (January to December) between 9am to 10am, using acidified plastic bottles. Water sample for dissolved oxygen, which was collected using $500 \mathrm{ml}$ Nessler bottles at about 12 noon. Air and water temperatures were determined in situ by 2 min. immersion of mercury in bulb thermometer. Transparency was measured using a $25 \mathrm{~cm}$ secchi disc. Other physico-chemical parameters were measured based on methods described in APHA (1989).

\subsection{Data analysis}

Data obtained from the study were expressed as mean \pm S.D of triplicate determinations. Differences in means were compared using analysis of variance (ANOVA) at $\mathrm{p}<0.05$. Where the difference in ANOVA is significant least significant difference (LSD) was used to separate means.

\section{RESULTS}

Mean values of physicochemical parameters in the 3 stations are presented in Figures 2-12.

\section{Air temperature $\left({ }^{\circ} \mathbf{C}\right)$}

Air temperature varied significantly $(\mathrm{p}<0.05)$ at the study stations. The highest mean air temperature value $(35.76 \pm 0.01$ ${ }^{\circ} \mathrm{C}$ ) was recorded in March while the lowest mean value $\left(25.52 \pm 0.00{ }^{\circ} \mathrm{C}\right.$ ) was obtained in July (Figure 2). Station 2 with the highest mean air temperature $\left(35.76 \pm 0.01^{\circ} \mathrm{C}\right)$ is significantly higher $(\mathrm{p}<0.05)$ than station 1 with the lowest mean value $\left(25.52 \pm 0.00{ }^{\circ} \mathrm{C}\right)$ and station $3\left(25.90 \pm 0.28{ }^{\circ} \mathrm{C}\right)$ which are not significantly different from each other. 


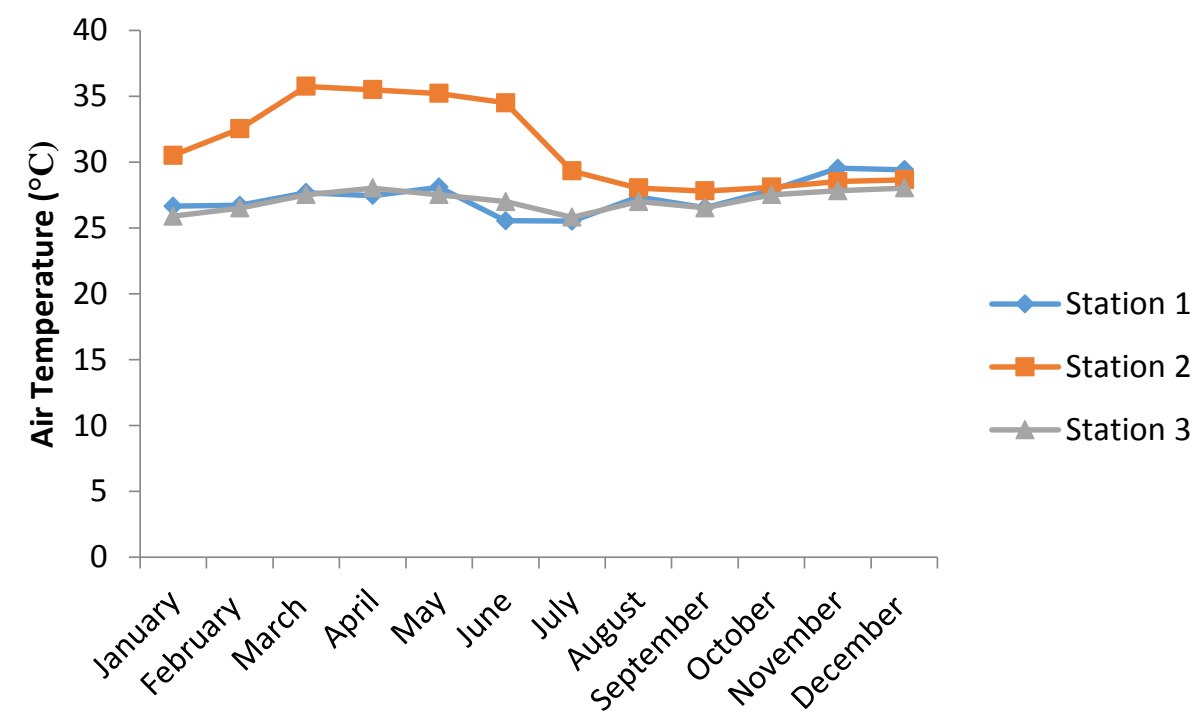

Figure 2: Mean variation in air temperature $\left({ }^{\circ} \mathrm{C}\right)$ in relation to stations of River Idemili.

\section{Water temperature $\left({ }^{\circ} \mathrm{C}\right)$}

Mean water temperature values for the study stations varied significantly $(\mathrm{p}<0.05)$ from $25.15 \pm 0.07{ }^{\circ} \mathrm{C}$ at station 1 in July to
$30.03 \pm 0.01{ }^{\circ} \mathrm{C}$ at station 2 in February (Figure 3) in the three study stations. Station 2 is significantly higher $(\mathrm{p}<0.05)$ than stations 1 and 3 which are not significantly different from each other.

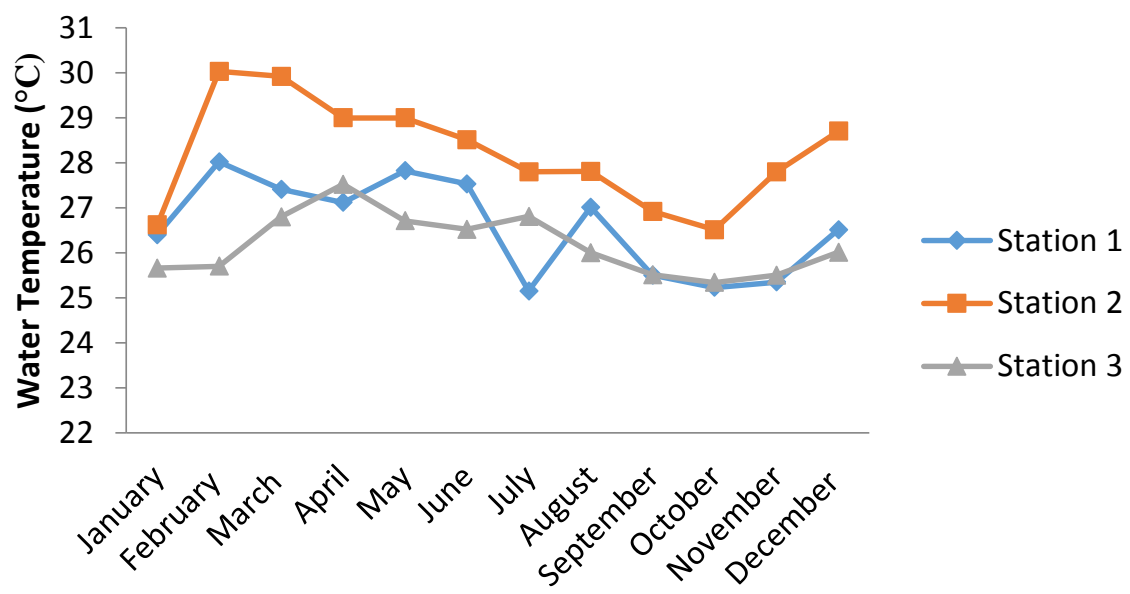

pH

Figure 3: Mean variation in water temperature $\left({ }^{\circ} \mathrm{C}\right)$ in relation to stations of River Idemili.

The mean $\mathrm{pH}$ values of River Idemili did not vary significantly ( $\mathrm{p}>0.05$ ) from $5.00 \pm 0.00$ at station 1 in November to $6.76 \pm 0.04$ at station 3 in September in the three stations (Figure 4).

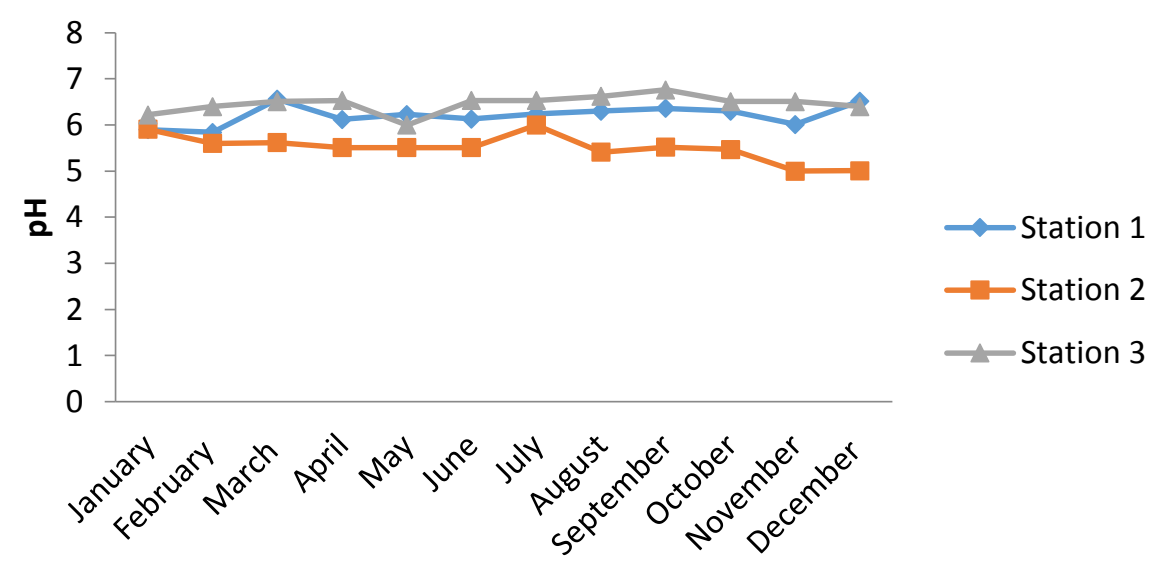

Figure 4: Mean variation in $\mathrm{pH}$ in relation to stations of River Idemili. 


\section{Turbidity (NTU)}

Turbidity varied during the study. The minimum value $(12.02 \pm 0.02 \mathrm{NTU})$, station 1 and maximum value $(53.00 \pm 0.00 \mathrm{NTU})$, station 3 were respectively obtained in
November and May (Figure 5). One-way analysis of variance revealed that the mean turbidity values in the three stations were significantly different $(\mathrm{p}<0.05)$. Station 3 is significantly lower $(\mathrm{p}<0.05)$ than stations 1 and 2 which are not significantly dissimilar.

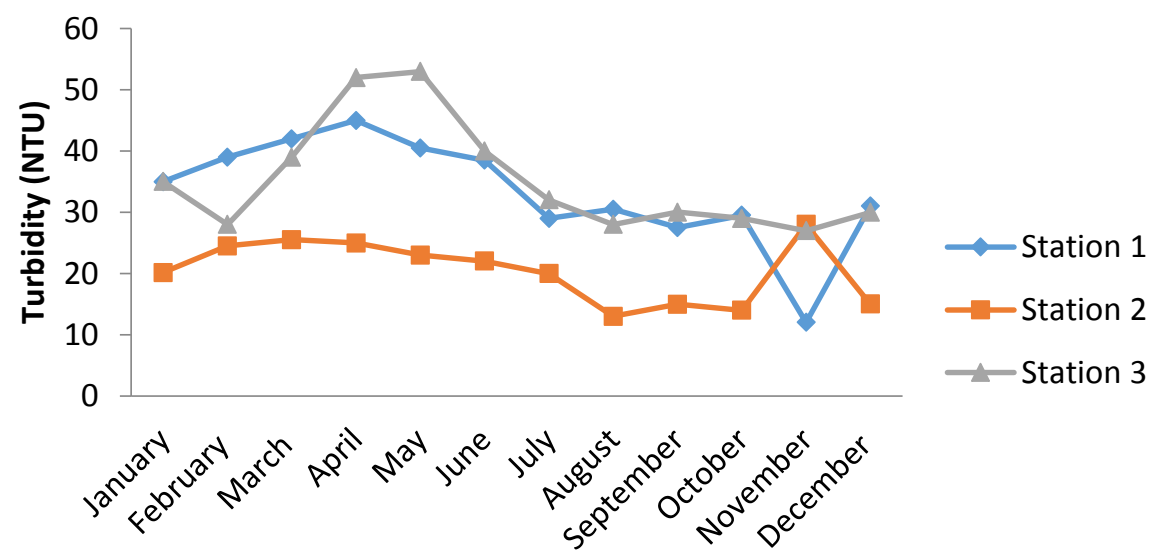

Figure 5: Mean variation in turbidity (NTU) in relation to stations of River Idemili.

\section{Dissolved Oxygen (mg/l)}

Figure 6 revealed that the maximum mean value of dissolved oxygen was recorded in station $1(5.48 \pm 0.02 \mathrm{mg} / \mathrm{l})$. This was followed by station $3(5.45 \pm 0.00 \mathrm{mg} .1)$. The minimum mean value of dissolved oxygen was recorded in station 2 $(1.03 \pm 0.04 \mathrm{mg} / \mathrm{l})$. Station 2 is significantly lower $(\mathrm{p}<0.05)$ than stations 2 and 3 which are not significantly different from each other. The values of dissolved oxygen in the stations ranged from $1.03 \pm 0.00 \mathrm{mg} / \mathrm{l}$ (Station 2) in January to $5.48 \pm 0.00 \mathrm{mg} / \mathrm{l}$ (station 1 ) in July.

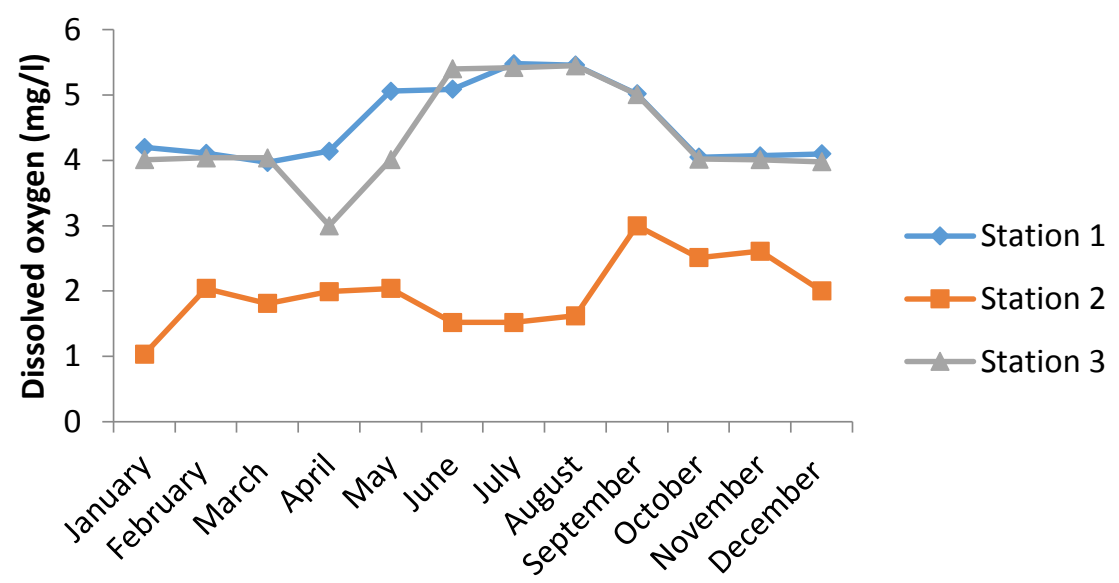

Figure 6: Mean variation in dissolved oxygen $(\mathrm{mg} / \mathrm{l})$ in relation to stations of River Idemili.

\section{Biochemical Oxygen Demand (BOD) (mg/l)}

Station 1 had the lowest biochemical oxygen demand mean value $(1.02 \pm 0.69 \mathrm{mg} / \mathrm{l})$ in March (Figure 7). The highest mean value $(5.53 \pm 0.04 \mathrm{mg} / \mathrm{l})$ was recorded in May. Station 2 with the highest mean value $(5.53 \pm 0.04 \mathrm{mg} / \mathrm{l})$ is significantly higher $(p<0.05)$ than stations 1 and 3 which do not differ significantly. 


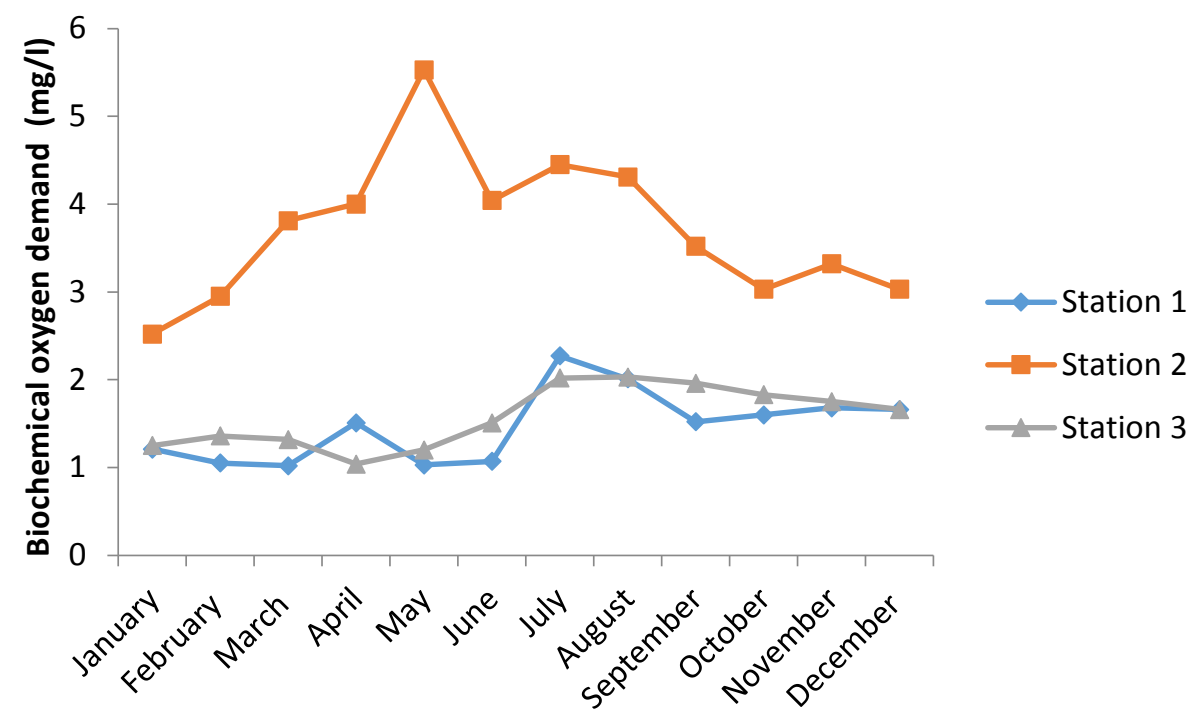

Figure 7: Mean variation in biochemical oxygen demand $(\mathrm{mg} / \mathrm{l})$ in relation to stations of River Idemili.

\section{Alkalinity (mg/l CaCO3)}

The mean values of alkalinity which ranged from $0.21 \pm 0.01 \mathrm{mg} / \mathrm{l}$ at station 1 and $4.22 \pm 0.03 \mathrm{mg} / \mathrm{l}$ at station 2 were both obtained in June (Figure 8). Analysis of variance result showed a significant difference $(\mathrm{p}<0.05)$ in alkalinity at the three stations. Station 2 is significantly higher $(\mathrm{p}<0.05)$ than stations 1 and 3 which are not significantly different from each other.

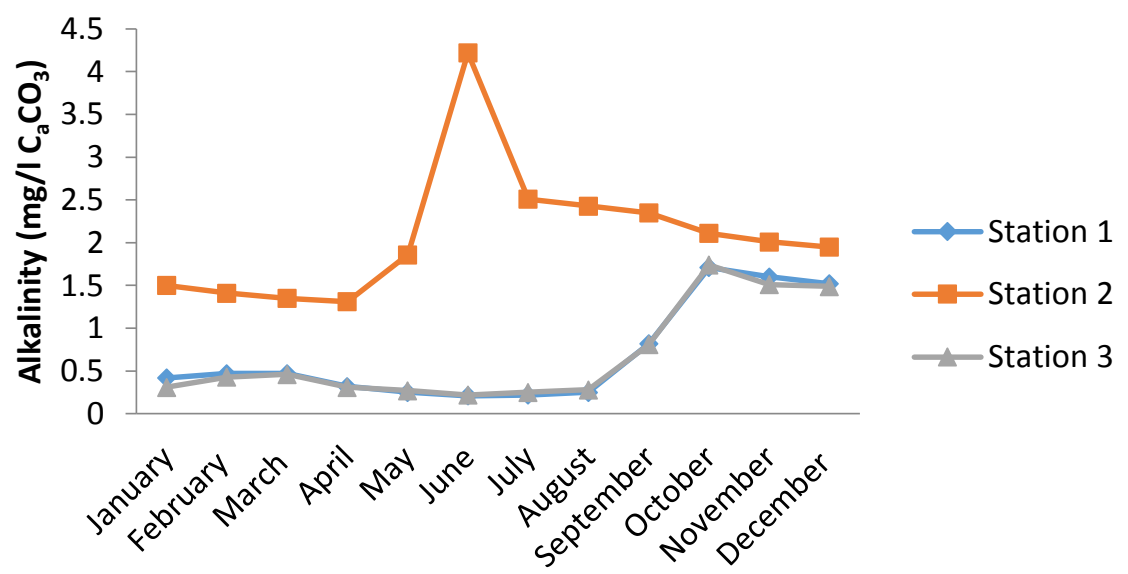

Figure 8: Mean variation in alkalinity $\left(\mathrm{mg} / \mathrm{l} \mathrm{CaCO}_{3}\right)$ in relation to stations of River Idemili.

\section{Hardness (mg/lCaCO$)$}

There was wide variation in mean values of hardness recorded during the study. Station 1 had the lowest mean value of $0.52 \pm 0.03 \mathrm{mg} / \mathrm{l}$ while station 2 had the highest mean hardness concentration $(4.02 \pm 0.03 \mathrm{mg} / \mathrm{l})$ (Figure 9). Station 2 is significantly higher $(\mathrm{p}<0.05)$ than stations 1 and 3 which did not differ significantly from each other. Hardness mean values in the months varied between $0.52 \pm 0.03 \mathrm{mg} / \mathrm{l}$ in April (station 1) and 4.02 $\pm 0.03 \mathrm{mg} / \mathrm{l}$ in July (station 2). 


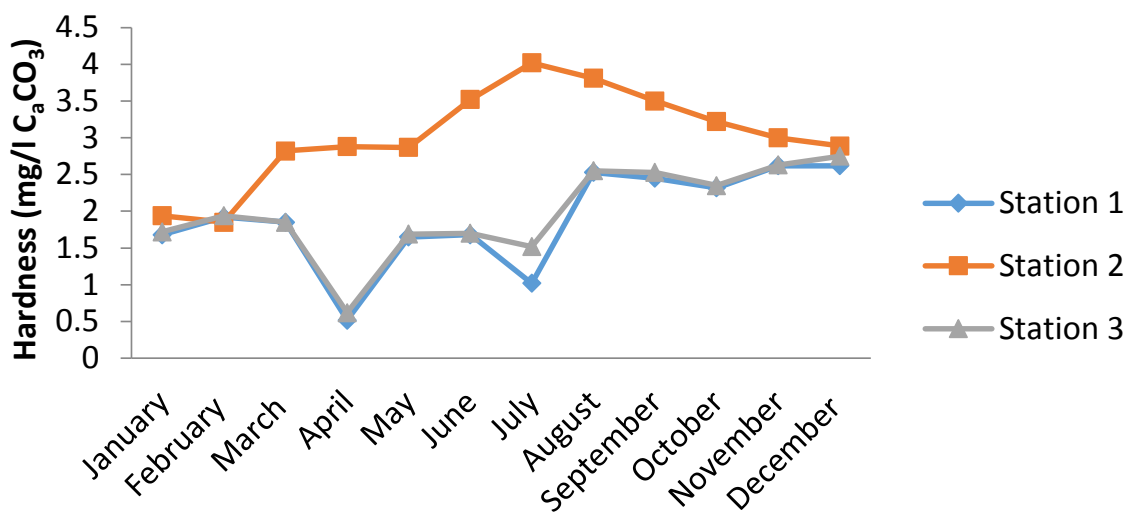

Figures 9: Mean variation in hardness $\left(\mathrm{mg} / \mathrm{l} \mathrm{CaCO}_{3}\right)$ in relation to stations of River Idemili.

\section{Nitrate-nitrogen concentration $(\mathrm{mg} / \mathrm{l})$}

The mean concentration of nitrate-nitrogen recorded for the three stations ranged from $3.52 \pm 0.03 \mathrm{mg} / \mathrm{l}$ at station 1 to $6.82 \pm 0.03 \mathrm{mg} / \mathrm{l}$ at station 2 (Figure 10). Station 2 with highest mean value $(6.82 \pm 1.03 \mathrm{mg} / \mathrm{l})$ was significantly higher $(\mathrm{p}<0.05)$ than stations 1 and 3 . The highest mean concentration value $(6.82 \pm 1.03 \mathrm{mg} / \mathrm{l}$ (station 2) and the lowest mean value $(3.52 \pm 0.03 \mathrm{mg} / \mathrm{l}$, station 1$)$ of nitratenitrogen were recorded in September and January respectively.

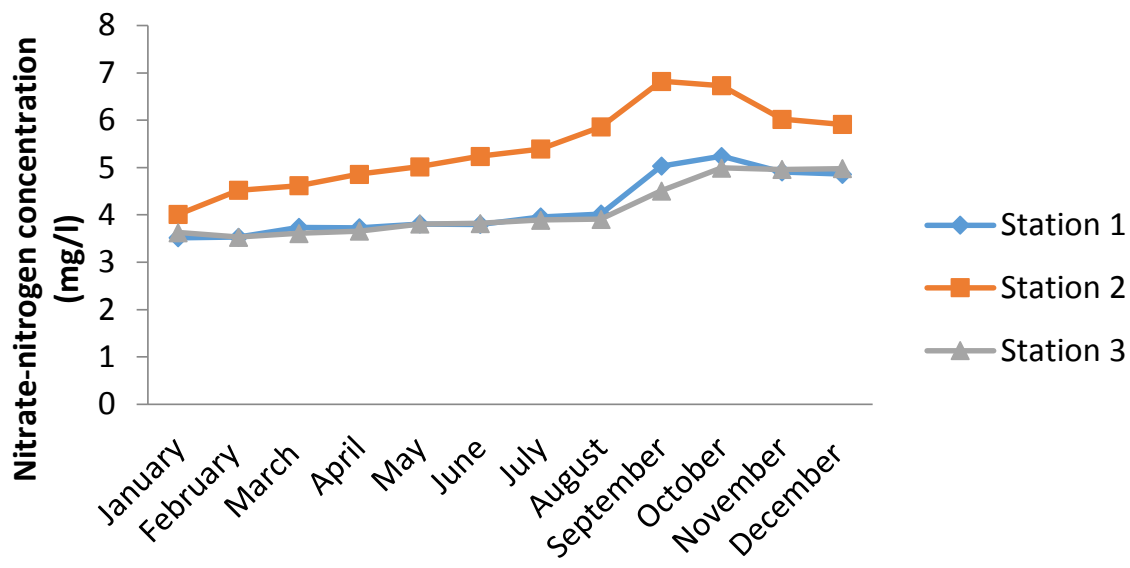

Figure 10: Mean variation in nitrate-nitrogen $(\mathrm{mg} / \mathrm{l})$ concentration in relation to stations of River Idemili.

\section{Phosphate-phosphorus concentration (mg/l)}

Figure 11 showed that the range of mean phosphatephosphorus values recorded during the study was $0.02 \pm 0.01$ $\mathrm{mg} / \mathrm{l}$ at station 1 in April and May, and 3.13 $\pm 0.04 \mathrm{mg} / \mathrm{l}$ at station 2 in July. The mean concentrations of phosphatephosphorus at station 2 is significantly higher $(\mathrm{p}<0.05)$ than that of stations 1 and 3 which are not significantly different form each other.

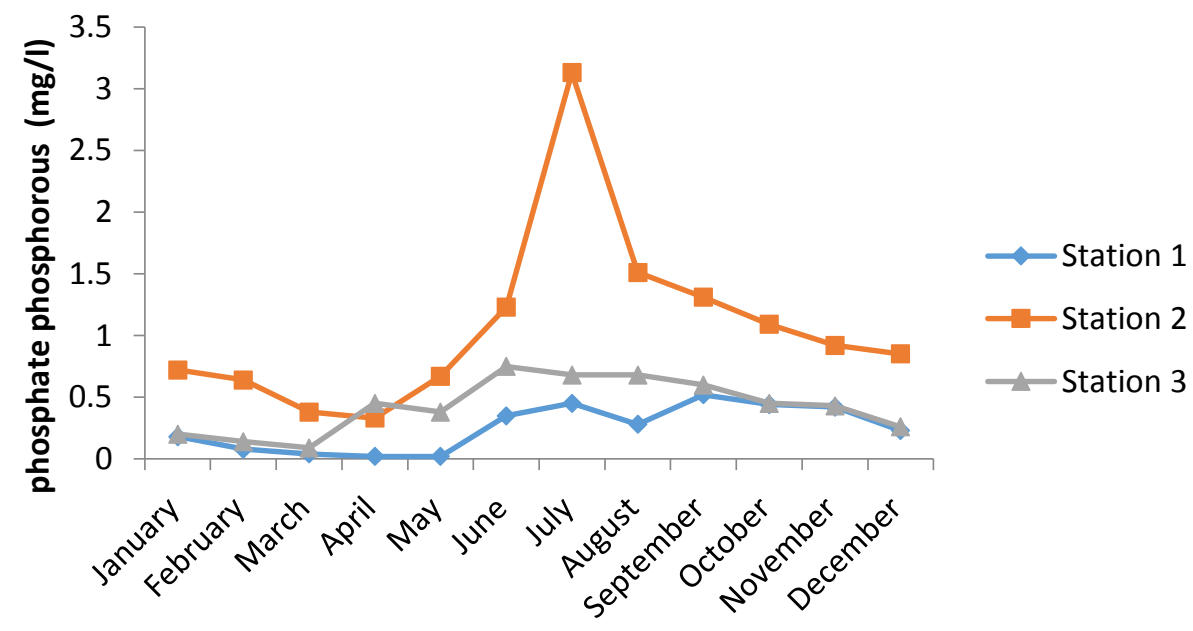

Figure 11: Mean variation in phosphate-phosphorous $(\mathrm{mg} / \mathrm{l})$ in relation to stations of River Idemili. 


\section{Conductivity $\left(\mu \mathrm{scm}^{-1}\right)$}

The lowest mean value for conductivity was recorded at station $1(31.02 \pm 0.01 \mathrm{mg} / \mathrm{l})$ in January (Figure 12) while the highest mean value of $52.21 \pm 0.05 \mu \mathrm{scm}^{-1}$ was recorded at station 2 in October. The mean conductivity values at the three stations are not significantly different $(\mathrm{p}>0.05)$.

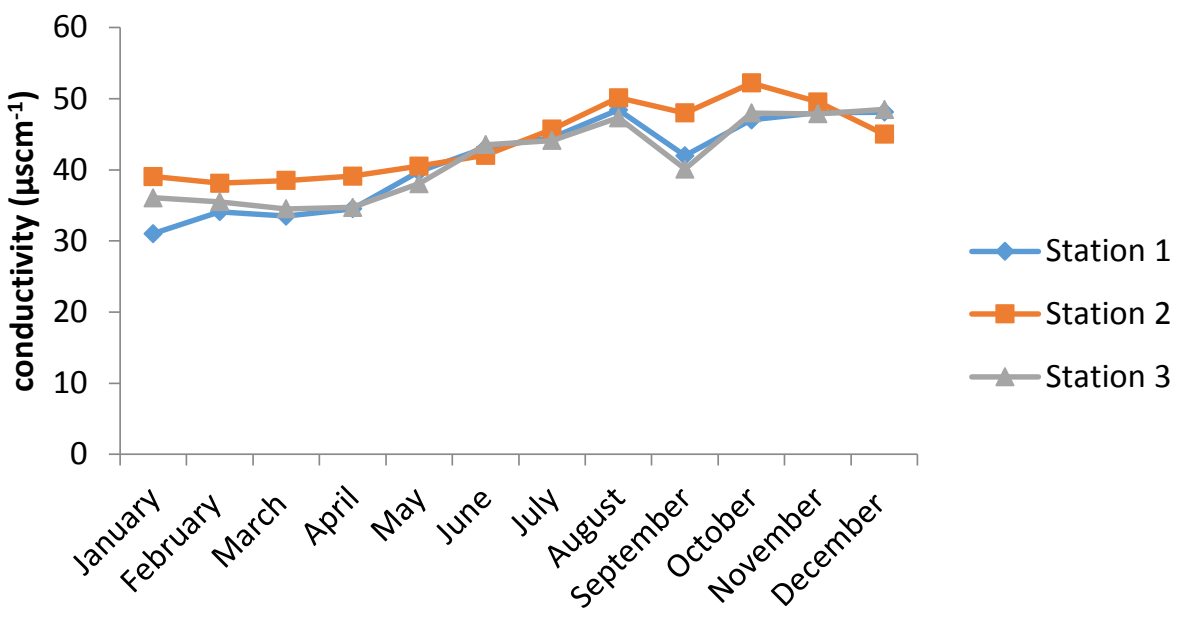

Figure 12: Mean variation in conductivity $\left(\mu \mathrm{scm}^{-1}\right)$ in relation to stations of River Idemili.

\section{DISCUSSION}

The mean air and water temperature range recorded from River Idemili are typical of tropical rivers. Water temperature falls within the surface water stipulated range of $25-30{ }^{\circ} \mathrm{C}$ for aquatic organisms (WHO, 1984). The maximum water temperature obtained in station 2 can be attributed to abattoir effluent discharge from the abattoir located around this station. Temperature rise depends on the amount of heat discharge, the mode of release, the properties and quantity of receiving waters, climate and weather (Haslam, 1990; Reheem and Morenikeji, 2008). An increase in temperature will lead to an increase in the rate of chemical reactions and formation of dangerous complexes. It also shortens the life cycles of some invertebrates in a river below a heated discharge (Raheem and Morenikeji, 2008).

$\mathrm{pH}$ measures the acidity or basic nature of solution (Chapman, 1996). The maximum $\mathrm{pH}$ in station 3 may be due to the photosynthetic activities of algal and plant growth in this station. $\mathrm{pH}$ is a vital environmental characteristic that decides the physiological, metabolic survival, and growth of aquatic organisms (Ramanathan et al., 2005). The mean pH recorded indicates that River Idemili was slightly acidic. Normal biological activity is restricted to 6-8, for natural water (Adakole and Anunne, 2003; Adakole, et al., 2008). pH varied slightly at the study stations with an approximate mean range of $6.8 \pm 0.04$ to $5.00+0.00$. This is in consonance with the observation of Wetzel (1975) that, low $\mathrm{pH}$ are found in natural water rich in dissolved organic matter. The low variability of $\mathrm{pH}$ value could be as a result of abattoir wastes not having significant effect on the $\mathrm{pH}$ of the River. Hynes (1975) has attributed low variability to streams being resistant to $\mathrm{pH}$ changes to chemical buffering effects. Although definitive, $\mathrm{pH}$ range of the aquatic systems is an important indicator of the water quality and the extent of pollution in watershed area (Adakole, 2007). Ibemenuga and Inyang (2007) recommended a $\mathrm{pH}$ range of 6.5-9.5 as suitable for aquatic life.
Turbidity was highest in station 3 as a result of excessive algal growth, riparian vegetation, in addition to the abattoir effluent transported downstream from station 2. Turbidity measures the clarity or cloudiness of water. The more suspended solids in the water the murkier it seems and the higher the turbidity (Rao, 1993). High turbidity will reduce primary production and also oxygen levels in pond which will increase the susceptibility of fish to fungal diseases (Boyd, 1979).

Dissolved oxygen is an important gas, necessary for respiration of aquatic biota hence Adeniji (1986) described it as one of the most important substances which aquatic organisms cannot survive without. Dissolved oxygen is a relative measure of the amount of oxygen that is dissolved or carried in a given medium (Chiya and Izumi, 1995). The minimum concentration of dissolved oxygen in fresh water necessary for aquatic fauna to live in is about $5 \mathrm{mg} /$ litre (Odiete, 1999). Dissolved oxygen mean value obtained for the three stations ranged from $1.03 \pm 0.04 \mathrm{mg} / \mathrm{l}$ in station 2 to $5.48 \pm 0.2 \mathrm{mg} / \mathrm{l}$ in station 1 . These values were lower than the value Offem et al. (2011) reported for Calabar River, and the WHO (2004) limit of $6.0 \mathrm{mg} / \mathrm{l}$. The low dissolved oxygen recorded during the study could be attributed to high organic pollution. BOD which measures organic pollution of aquatic bodies was maximum in station 2 . This could be due to abattoir effluents containing large amounts of organic waste which was as a result of the abattoir located here.

Low alkalinity values were recorded in the three stations. ANOVA revealed significant difference $(\mathrm{p}<0.05)$ in the mean concentrations of alkalinity in the three stations.

The mean hardness values for the stations which ranged from $0.52 \pm 0.03 \mathrm{mg} / 1 \mathrm{CaCO}_{3}$ in station 2 falls within the classification of soft water. This probably was due to inflow of rain water which neutralizes the chemical composition of the abattoir effluent within the river. The maximum mean value of hardness recorded in station 2 could be due to concentration effect from entry of organic effluents and 
evaporation due to high temperature based on the hardness classification of water; soft $\left(0-55 \mathrm{mg} / \mathrm{lC}_{\mathrm{a}} \mathrm{CO}_{3}\right)$, slightly hard (56-100 mg/lCaCO 3$)$, moderately hard (101-200 mg/ $/ \mathrm{CaCO}_{3}$ and 201-500 mg/lCaCO 3 as modified from Outreach Department (OD) of natural Water Resources Institute Kaduna (1997).

Nitrate-nitrogen is among the common nitrogen compounds occurring in dissolved particulate and gaseous forms. Nitratenitrogen is soluble and easily absorbed by aquatic biota. Generally, the mean value $(4.57 \pm 0.9 \mathrm{mg} / \mathrm{l})$ of nitrate concentration in River Idemili was lower than the WHO (2004) limits of $10 \mathrm{mg} / \mathrm{l}$ for rivers and streams. Odiete (1999) noted that a characteristic feature of most tropical waters is low rate which results in rapid utilization of nutrients. The low level of nitrate- nitrogen also indicates the good health status and self-purification capacity of the river despite the discharge of abattoir waste into it as excessive concentrations of nutrients can over stimulate aquatic plant and algal growth and cause oxygen depletion and eutrophication which may deprive fish and invertebrates of available oxygen in the water (Agwa et al., 2013).

Phosphate-phosphorus is among nutrient determinants of phytoplankton productivity and hence fish production (Welcome, 1978; Boyd and Lichtkoppler, 1979; Wetzel and Likens, 1978; King, 1998). The concentration of phosphatephosphorous above $0.5 \mathrm{mg} / \mathrm{l}$ was an indication of pollution (Agarwal, 1991; Raheem and Morenikeji, 2008). This indicates that station 1 with the maximum mean phosphatephosphorous concentration $(1.6 \pm 0.75 \mathrm{mg} / \mathrm{l})$ is polluted. This station is mostly polluted compared with station $1(0.25 \pm 0.19$ $\mathrm{mg} / \mathrm{l})$ upstream and station $3(0.42 \pm 0.23 \mathrm{mg} / \mathrm{l})$ downstream.

Electrical conductivity in natural waters depends on the geology, land use, flow, runoff, ground water inflows' temperature, evaporation and dilution. The higher mean value $45.71 \pm 0.01 \mathrm{uscm}^{-1}$ recorded in station 2 may be attributed to concentration effect of the water due to abattoir effluent discharged through this point into the river. Conductivity of freshwater ranged from $10-1000 \mu \mathrm{scm}^{-1}$ but may exceed $1000 \mu \mathrm{scm}^{-1}$ (Asuquo, 1999; Offem et al., 2011). The mean value of conductivity recorded for the three stations is within the range for fresh water.

\section{CONCLUSION}

The result of this study revealed that the abattoir effluents discharged into River Idemili impacted negatively on the physical and chemical characteristics of the river. Since water quality attributes are prime factors that influence the survival of aquatic life, there is need to treat abattoir effluents before discharge into the river.

\section{REFERENCES}

Adakole, J.A. (2007). Bacteriological quality of an urban stream in Northern Nigeria. Journal of Aquatic Sciences, 22(1):1-10.

Adakole, J.A. and Anunna, P.A. (2003). Benthic macro invertebrates as indicators of Environmental quality of an urban stream, Zaria, Nigeria. Journal of Aquatic Sciences, 18(2):85-92.
Adakole, J.A., Abulode, D.S. and Balarabe, M.I. (2008). Assessment of Water Quality of a Man-Made Lake in Zaria, Nigeria (Sengupta, M. and Dalwani, R. eds.). Proceedings of Taal 2007: The 12th World Lake Conference, 1373-1382.

Adeniji, H.A. (1986). Some Limnological precautions for fish farmers. Fisheries enterprises and information Brochure in commemoration of the 5th annual conference of the Fisheries Society of Nigeria (FISON) Set. 22nd - 25th, 54-56.

Agarwal, S.K. (1991). Pollution Ecology, Humanshu Publications Udaipur.

Agwa, O.K., Sito, E. and Ogugbue, C.J. (2013). A Spatial Assessment of the Microbiological and Physicochemical Quality of a Stream Receiving Raw Abattoir Waste. Middle-East Journal of Scientific Research, 14(7):879-886.

Aina, E.G. and Adipe, N.O. (eds) (1996). Water quality monitoring and environmental status in Nigeria. FEPA monography 6, Abuja, Nigeria. Pp. 239.

APHA, (1989). Standard Methods for the examination of water and waste waters. 18th edition, American Public Health Association Washington D.C. 1134pp.

Arimoro, F.O. and Osakwe, E,1. (2006). Influence of sawmill wood wastes on the distribution and population of macro benthic invertebrates in Benin River at Sapele, Niger Delta, Nigeria. Chemistry and Biodiversity, 3:578-592.

Arimoro, P.O. and Ikoni, R.B. (2008). Response of macro invertebrates to abattoir waste and other anthropogenic activities in municipal stream in Niger Delta, Nigeria. Environmentalist, 28:8598.

Asuquo, F.E. (1999). Physico-chemical characteristics and anthropogenic pothition of the surface waters of Calabar River, Nigeria. Global Journal of pure and Applied Science, 5(4);595-600.

Boyd, C.E. (1979). Water quality in warm water fish pond. Craft masters printers, INC. Opelika Alabama.

Boyd, C.E. and Lichkoppler, F. (1979). Water quality management in pond fish culture. Int. Center for Aquaculture, Agricultural experiment station, Auburn Univ, research and Development. Series No. 22 Project AID/DSANG0039, 30PP.

Calamari, D. and Naeve, H. (eds.) (1994). Review of pollution in the African aquatic environment. CIFA Technical Paper No, 25 FAO, Rome, 118pp.

Chapman, D. (1996). Water Quality Assessment - A guide to use of biota sediments and water environmental monitoring. $2^{\text {nd }}$ edition EPFN. Spon, London. 66pp.

Chiya, N. and Izumi, N. (1995). "XAFS studies of some precipitation and colouration reaction used in analytical chemistry". Physical condensed matter, 208-209: 387-388.

Guputa, G.K. and Shunkle, R. (2006). Physico-chemical and bacteriological quality in various sources of drinking water from Auriya District (UP) Industrial Area, Pollution Research, 23(4):205-209.

Haslam, S.M. (1990). River Pollution: an Ecological Perspective. Behaven Press, p.253. 
Hynes, B.N, (1975). The stream and its valley: Edgardo Baldi Memorial Lecture. Verhandlungen International Vereinigung der Limnologie, 19: 1-5.

Ibemenuga, K.N. and Inyang, N.M. (2007). Physico-chemical characteristics of tropical stream in Nigeria. Journal of Biological Research and Biotechnology, 2: 275-281.

King, R.P. (1998). Physico-chemical indices of the fisheries potential of Nigeria rainforest pond. Journal of Aquatic Sciences, 13: 49-54.

Mason, C.F. (1996). Biology of freshwater pollution. 3rd edition. Longman Group Limited, UK, 258pp.

Odiete, W.O. (1999). Environmental physiology, Animals and Pollution. Diversities Publ. Limited, Lagos. 261pp.

Offem, B.O., Ayotunde, F.Q., Ikpe, G.U., Ochang, S.N. and Ada, F.B. (2011). Influence of seasons on water quality, Abundance of fish and plankton species of Ikwori Lake, South-Eastern Nigeria. Fisheries and Aquaculture Journal, 2011: Faj-13 $\mathrm{http//astonjournals.com/faj.}$

Outreach Department (OD) National Water Resources InstituteKaduna (1997). Water Quality Testing and Control. 115pp.

Patil, D.R. and Tijane, R.V. (2001). Investigation of suspected carcinogen $\mathrm{Cr}$ (iv) and its control. Journal of J.ld. Pollution Control course, 18(1): 43-47

Raheem, N.K. and Morenikeji, O.A. (2008). Impact of abattoir effluents on surface waters of the Alanuyo Stream in Ibadan. Journal of Applied Sciences and Environmental Management, 12(1): 73-77.

\section{$\underline{\text { How to cite this article }}$}

Ibemenuga, K. N. (2018). Environmental Impact of Abattoir Effluents on Surface Waters of River Idemili. Tropical Journal of Applied Natural Sciences, 2(2): 1-9. Doi: https://doi.org/10.25240/TJANS.2018.2.2.01.

Licensed under a Creative Commons Attribution 4.0 International License
Rao, K.S. (1993). Practical Ecology-1st edition school of studies in Zoology. Vikram University. Pp. 16-17.

Remanathan, N., Padmavatly, P., Francis, T., Athithian, S. and Selvaranjitham (2005). Manual on polyculture of tier shrimp and carps in firewater. Tmail Nadu vertermany and animal sciences University, Fisheries college and research Thothukudi. Pp. 1-161.

Singh, R.P. and Mathur, P. (2005). Investigation of variation in City, Rajasthan; Indian Journal of Environmental Science, 9(1): 5761.

Welcome, R.L. (1978). Some factors affecting the catch of tropical river fisheries. Welcome, R.L. (ed). In: Africa, Boujumbra, Burundi, 21-23 November, 1977. Review and experience papers. CIFA Tech. Pap/Doc/Tech. CPCA., 5:266-275.

Wetzel, R.G and Likens, G.E. (1978). Limnological analysis. W.B. Saunders Company, USA, 375pp.

Wetzel, R.G. (1975). Limnology. Saunders college publications, New York. 222pp

WHO (World Health Organization) (1984). Guidelines for Drinking Water Quality. Volume 2. Health Criteria and other supporting information, Geneva. 335pp.

WHO (World Health Organization) (2004). Guidelines for Drinking Water Quality. 3rd ed., Recommendation, Geneva 515pp.

Zabbey, N. and Hart, A.I. (2006). Influence of some physicochemical parameters on the composition and distribution of benthic fauna in Woji creek, Niger Delta, Nigeria. Global Journal of Pure and Applied Sciences, 12(1): 1-5. phsico-chemical characteristics of a freshwater reservoir of Aginer

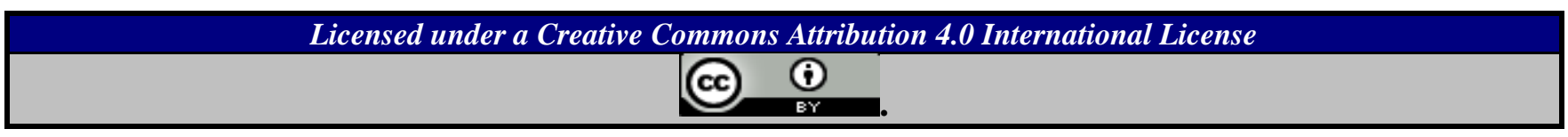

